\title{
HOW ARE THEY RACIALIZED? \\ RACIAL EXPERIENCES OF CHINESE GRADUATE STUDENTS
}

\author{
Ying Wang \\ University of Maryland, College Park
}

In recent years, the population of students coming from China to pursue higher education, especially graduate education, in the United States has increased significantly. The annual statistics gathered by the Institute for International Education (2009) show that during the 20082009 academic year, there were 98,235 Chinese students at institutions of higher education in the United States. Chinese students are the second largest group of foreign students in the United States-only one country, India, sends more students to American campuses (IES 2009). Compared to earlier waves of Chinese immigrants, today's Chinese students have two new characteristics: Chinese students come to the United States in search of education, while earlier Chinese immigrants left their home country for political and economic reasons (Segal 2002); moreover, Chinese students are not yet Chinese Americans, and they are excluded from many ethnic studies.

There have been studies on Asian American students, but most were focusing on high school students and undergraduate students, and no one has particularly looked at Asian international students in graduate schools (Louie 2004; Lee 1996; Pyke and Dang 2003). Although the population of Chinese graduate students is exploding and they are present in every part of the United States, the issues Chinese graduate students face in terms of their racial experiences in the United States remains absent in the literature. My research project not only fills the gap by exploring micro-level racial experiences of Chinese graduate students, but also provides a unique window to the experiences of Asian graduate students in a southwest urban setting, which has a small Asian population.

Because their home country, China is a racially homogenous country, Chinese students do not encounter race and racial discrimination until they come to the United States. Through their interactions with people of other racial groups such as White, Black, and Latino, Chinese students begin to realize a great change in their racial identity and status. In their home country, they identified as "Chinese," but once they came to the United States, they became "Asians" or "Asian Americans." Not only do 
they receive a new identity, but they confront the stereotypes given by the dominant society to Asians such as the "model minority," "math nerds," etc. While they used to belong to the dominant group in their home country, now they encounter a downward mobility in their racial status-from the dominant group to the racial minority in a white-dominated society. Along with experiencing the change in identity and status, some of them experience unequal treatment, prejudice and discrimination during their time of study in the United States (Fong 2002; Andrea Louie 2004; Tuan 1998).

The current research utilizes the racial formation framework (Omi and Winant 1994) because it works best to explain how race occurs at the micro-level. Within this framework, I am trying to explore how race shapes the experiences of Chinese graduate students by using the ethnographic research method. This paper has several aims: (1) to explore the racial experiences of Chinese graduate students have; (2) to analyze those experiences in terms of the dynamics underlying them; (3) to seek a solution for any possible problems.

\section{Methodology}

The setting of my study, Southwestern University, is one of the largest public higher institutions in the United States. It has a diverse student population especially widely known as a Hispanic-Serving institution, representing a wide cross-section of cultures and backgrounds. Until 2005, the racial breakdown of all students and of graduate students at Southwestern main campus is shown in Table 1.

TABLE 1

\begin{tabular}{|l|c|c|}
\hline \multicolumn{3}{|c|}{ Race/Ethnicity of Students } \\
\hline Race/Ethnicity & All students & Graduate students \\
\hline Non-Hispanic White & $48.1 \%$ & $52.0 \%$ \\
\hline Latino/a & $30.0 \%$ & $17.5 \%$ \\
\hline American Indian & $5.8 \%$ & $4.0 \%$ \\
\hline Asian/Pacific Islander & $3.4 \%$ & $2.3 \%$ \\
\hline African American & $2.6 \%$ & $1.6 \%$ \\
\hline International & $3.3 \%$ & $13.5 \%$ \\
\hline No Response & $6.8 \%$ & $9.1 \%$ \\
\hline
\end{tabular}

Since I want to present the process of racial formation at the micro level, I used qualitative methods to explore lived experiences and perceptions of individual Chinese students. The data for this paper comes from interviews, ethnographic fieldwork, and observations conducted in 2004 
and in 2005. I entered classrooms and labs including sitting in undergraduate-level classes taught by Chinese Teaching Assistants (TA) and spent some time observing Chinese Research Assistant (RA)'s work and activities in the lab. Fieldnotes and informal conversations with those Chinese students I observed were taken. I conducted 11 in-depth, semistrucured, open-ended interviews with Chinese graduate students from different Southwestern departments. Eight are male and three are female. Interviewees were asked open-ended questions on racial identity, understandings of the "model minority" stereotype, racial experiences as graduate students at Southwestern and in public places, feelings about being a Chinese student in America, and their future career plans. The format of the interviews was designed to allow people the flexibility to speak about their experiences and perceptions in ways that are significant to them.

All of the interview subjects were selected from Southwestern Chinese graduate students. My selection of interviewees is based on a targeted "snowball" procedure. I randomly selected my interviewees from the list of Chinese graduate students provided by a Chinese student association at Southwestern. Diversity of departmental origin, gender, and length of staying in the United States were ensured when the selected was conducted. However, to ensure the anonymity of my informants, I generalized their departments to be "Natural Science" and "Social Science" in the narratives instead of disclosing specific information.

\section{"Who Am I?": Understandings of Race and Racial Identities}

When Chinese students come to the United States, not only do their racial identities change, but they also encounter different racial dynamics. Race used to be viewed as something "far from real life" when they were in China, but it now becomes something related to everyday life. Coming from a racially homogeneous country where people do not have much phonotypical differences, Chinese students get used to people with "black hair, black eyes" around them, and get used to be a member of majority. Now they are in a multi-racial country, where they are minorities, this great change makes them feel shocked, frustrated and confused. They are confused by race and ethnicity - many Chinese students I interviewed could not see the differences between race and ethnicity; also they are confused by new terms others use to identify them. In the United States, people from all Asian countries witness their different national identities disappear into a narrow racial categorization, which is subsumed by the Asian/Asian American label (V. Louie 2004).

Chen (female, from a Social Science department) told me her understandings of race. She never thought about race when she was in China because she "did not have to." When she watched TV or listened to the radio, she heard racial conflicts, racial wars, racial problems going on in 
America and Africa, she felt that race was far from her life, because that was "something that happened elsewhere." Although Chinese students "did not have to" think about race in China, they cannot avoid encountering race in the United States. When asked about understandings of race in America in particular, Chen said, "I know some minority people are discriminated against here. . this is unfair. I feel race is no longer far away, it's in my everyday life now."

Feng (male, from a Natural Science department) said, "Unlike China, there are racial problems in the United States. I think the U.S. government needs to take time to solve them. And I became minority since I got here. . .you know what? Chinese is the group with the largest population all over the world. . how come we Chinese became minority in America? I'm frustrated."

Wu (male, from a Natural Science department) described his feelings of first impression of America, "Los Angeles airport was my very first stop. When I was walking at the airport, from a terminal to another. . .I was shocked. . .shocked to see people of all skin color. . .various kinds of people. . .various hair colors, skin colors, eye colors . . .all kinds. I got used to black hair, black eyes around me, so I was really shocked."

When I asked them what race other people (including Whites, other Asians, Hispanic, African American people, etc) thought they were, answers were very similar. They told me that many American people could not tell the differences among Chinese, Japanese, Korean and Vietnamese, so they were always thought to be from some Asian groups. From my interviews, Chinese students prefer to be identified as "Chinese" rather than "Asian" mainly because that they are unwilling to overlook the differences among Asian groups. Hence, they are reluctant to accept the general racial categories that are given by the American mainstream society as they said they would identify themselves as Chinese if they "have a choice." Do they have a choice? As stated by Omi and Winant (1994), racial dynamic "establishes often contradictory parameters of racial identity into which both individuals and groups must fit" (Omi and Winant 1994, 3). Therefore, Chinese students "must fit" into the summary racial category in the United States, and also "fit" into the stereotypes associated with that racial category. This process of "fit," which is indeed the process of their racial awareness, is their first stage of racialization. They are racialized as "Asian"- a minority group in the white-dominated society; they are no longer members of a majority, instead, they become minorities; and they also have to encounter racial stereotypes, racism and racial problems associated with their new racial identities. 


\section{"That is Racism": Encountering the "Model MinORITY" STEREOTYPE}

When I questioned about understandings and reflections of the "model minority" stereotype, five of eleven Chinese students never heard of it. Other six students heard about this term and knew the meaning of it before I interviewed them. After I introduced and explained the "model minority" stereotype to those who never heard about it before, most of them seemed to reject it. Zhao, a male Chinese graduate student from a Natural Science department, who had not heard the "model minority" stereotype before, had these reflections:

I don't like to be viewed as "model minority." It is inaccurate. Working hard is a habit, and many Chinese students are studious. I spend more time on schoolwork than my Anglo American classmates do, but I don't often get better grades. Anglo students are also smart, some of them are as studious as Chinese. They can get better grades than me and other Chinese.

Feng and another Chinese student $\mathrm{Li}$, both of them had heard about "model minority" before; they reject the "model minority" stereotype not only because it "is not accurate" or "does not fit," but because of something behind the stereotype. In Feng (male, from a Social Science department)'s words: "sometimes we (Chinese) are good, but not always. Model minority is such a big hat, it's too large and too heavy, I don't like wearing it. It (model minority) reflects racism. Just think about it, why the Whites have the rights to judge who is good and bad, who is model minority and who is not model minority? Who make the criteria? They themselves created the criteria and they are using the criteria to evaluate us! Isn't that racism?" Li (male, from a Natural Science department) said, "This (model minority) is ridiculous. Whites are using this "model minority" as an excuse when they don't do well. The whole stereotype thing is just their trick." Similarly, Chen (female, from a Social Science department) mentioned that when some White students did worse than her in a math class, they said, "no wonder, you are Chinese!"

However, I also noticed that the impact of the model minority stereotype is not always negative, but both Lee (1996) and Louie's (2004) work only present the positive part of the model minority stereotype. From Zheng's narratives, her classmates assumed that she might be good in math since she was Chinese, and finally she helped them out and "felt good." To Zheng, the model minority stereotype provided her an opportunity to show her talent and to gain confidence-the consequence is positive. On one hand, we should be aware of the negative impacts of the model minority stereotype such as great pressure and racial conflict, but 
on the other hand, we also should admit that there are possible positive impacts of this stereotype. For example, Chinese students are considered a model to African Americans and Latinos who are assumed to be less intelligent, particularly in math and science.

I asked the participants whether they were not satisfied with current grades and many of them felt "it could be better." Feng and Zheng's answers were very similar. They thought that they deserved better grades because they worked so hard. Both Zhou and Zhao mentioned "Chinese" as a reason. Zhou's response was, "I've been studying this major for seven years (since undergraduate school). I'm really into it. I don't want others, I mean Americans, to say something like. . hey, you are Chinese, and this is the major you are supposed to be good at, but you got this grade?" Zhao said, "I came all the way from China so I need to prove that I'm distinct. Always, always distinct. . otherwise I can't get a job after graduation, because opportunities are rare for us." Zhou and Zhao are two examples of being "compelled to excel." Zhou struggled because he did not want "Americans" to look down on him and Chinese people; while for Zhao, who realized as a Chinese, if he wanted to seize the "rare" opportunities, he had to be "distinct." This resonates with Louie's finding that part of the reason why Chinese students and their families were compelled to excel was that they knew they would be discriminated against because of their race (V. Louie 2004).

Again, I cannot help thinking: what pushes them? Studies show that traditional Chinese culture (i.e. emphasis of education, respecting authority, etc), family (i.e. strong family ties, strict control from parents, family investment on education), and self-devoting into education all have significant positive effects on academic success of Chinese students (Kao 1995; Lee 1996; V. Louie 2004). But the effect of external pressure, especially the pressure from the model minority stereotype, remains an unanswered question in the literature, and it is very difficult to measure the effect. Moreover, as some Chinese students implied, they came all the way here to study so they had to seize the chance and to be distinct. This view may be common among international students from all over the world, because they have clear motivation and purpose when they come to the United States, and compared to American students, these international students are highly selected.

As stated by Vivian Louie, "the model minority stereotype powerfully informs everyday lives of Chinese American students, by shaping how people of other racial and ethnic groups view and interact with them, especially in school" (V. Louie 2004, 87). From my interviews, I found that this stereotype is playing an important role in disguising the difficulties and problems that Chinese students have encountered. With the model minority stereotype, professors and school administra- 
tions often assume that "Chinese students are doing well because they are Chinese" (V. Louie 2004). At Southwestern University, there are special programs with aims of helping and supporting Hispanic students, Native American students and African American students, however, there is no such a support program targeting Chinese or Chinese American students.

Pyke and Dang (2003) found that the racial beliefs, meanings, and stereotypes of the mainstream society shape how these Asian Americans think about coethnics, local identities deflect stigma from themselves. My findings are in accordance with Pyke and Dang's statements. As in Feng's words, he believed that "model minority" was a "racist" stereotype, so that he is very likely to feel offended when being called "model minority." Li, by viewing "model minority" as "ridiculous" and an "excuse" of Whites, is likely to reject this stereotype as well. In contrast, Zheng, who feels good after solving math problems for her classmates, is likely to have a positive attitude toward the stereotype. Eventually, their views will shape their relations to the institutions and other people (Omi and Winant 1994), and may have an impact on their future plans.

\section{The Existence of Discrimination: Lived Racial Experiences}

The racial experiences I reveal in this paper include unfair treatments they received from others, uncomfortable experiences they confronted, and discrimination against them, all because of their race. What is the difference in their experiences between different contexts? I hope not only to unravel and describe the sad, miserable, angry, disappointed aspects of Chinese students' life-the life which the institution and the society may not know about, but also explore how their experiences differ as contexts change.

Since all the Chinese students I interviewed hold assistantships, at Southwestern, they are not only students but also workers. As Chinese Teaching Assistants, they lack power, and do not have enough respect from the students they taught. While as Research Assistants, they are "exploitable workers"- they overwork, but do not earn much (some of them even earn very little). More importantly, compared to their White lab-mates/co-workers, Chinese students work much harder and are treated unequally. Two Chinese RAs believed that they have experienced discrimination.

Legal systems of discrimination such as "de jure" segregation had been eliminated since the 1960s, thus, today's racial discrimination and racial inequality were problems to be confronted only at an individual level (Omi and Winant, 1994, 131). My findings are in accordance with Omi and Winant's statement. None of Chinese students mentioned the institutional level discrimination (i.e. if the school refuses accepting stu- 
dents of color or puts them in less advanced programs). Rather, their experiences of discrimination are all at individual levels, such as being discriminated against by advisors, by store staffs and by doctors.

From the words of International Office staffs, there is only one incident about discrimination reported by Chinese students. However, from my interviews, several Chinese students felt discriminated against by their advisors but all they could do was switch to another advisor and change from RA to TA. By doing this, they were escaping from problems instead of solving them. Worrying about their legal status would be one of the reasons that Chinese students chose not to report their uncomfortable experiences. Moreover, racial discrimination is a sensitive issue, and today, we hardly see and encounter direct discrimination. All the discrimination experiences that Chinese students encountered were subtle and indirect. Chinese students doubted that whether they should "call it discrimination or not," not surprisingly, they hesitated to report the uncomfortable experiences.

Discrimination is a feature of U.S. society, the product of centuries of systematic exclusion, exploitation, and disregard of racially defined minorities (Omi and Winant 1994, 69). The roots of discrimination are in the racially organized social order. When Chinese students are in their home country, they never receive unfair treatment because of their race. Since they are the dominant group in China, they have the privilege. But they lost their privilege in the United States. Regardless of the type of discrimination - subtle or direct, racial discrimination is based on white supremacy. Receiving unfair treatment and racial discrimination, Chinese students are undergoing an important stage of racialization-they are racialized as exploitable workers, perpetual foreigners and the unprivileged racial group members.

\section{Future Outlooks: Plan After Graduation}

Unlike Asian Americans, Chinese students could be sojourners or permanent residents of the United States-they have the choice to go back to China or to stay after completing their study. United States is often viewed as the "dream place" in China, since Chinese students finally made it here, will they choose to stay or go back to their home country? Will the unhappy experiences affect their choice?

Certainly, it is a hard choice. When asked whether they would stay in the United States as permanent residents or they would go back to China after graduation, all of the Chinese students said they were "not sure." They used a lot of "maybe," "probably," and "I guess" in their narratives. Ten out of eleven Chinese students preferred working in the United States for a few years after graduation. Only Sun said he would probably go back to China to work if Chinese companies could offer him 
a good position. However, all of them said they were likely to eventually end up in China, because "China is home" and because their families are in China.

It is interesting that Chinese students hold up the importance of education along the lines of racial discrimination. Even if some Chinese students had uncomfortable experiences and felt unhappy, all of the Chinese students showed confidence about their future plans. They believed in meritocracy, they insisted that education would help them achieve social mobility, and they also believed that their race would not harm their careers as long as they were "good enough."

Although Zhao had the unhappy experience of being discriminated against by his advisor, he still believed that education would be his "way out." In his words, "I know it's hard for Chinese people to get a job in America, but I'll try my best. I think if I'm good enough, I'll be successful no matter what racial group I am from." Qian, the other Chinese student who had been discriminated against, said similarly, "finding a job would be hard after graduation, but I think there are some opportunities for Chinese. You can get the opportunities if you're distinct." Chen (female, from a Social Science department) said she was "not sure" whether she could find a job in the U.S. after graduation or not. In her words: "I know it would be really hard to find a job, as Chinese and as an international student. But I would like to try. You know, having a few years U.S. working experiences and then going back would be great. Well, if I can't get any job offer after graduation, I'll go back to China to work."

Chinese students' accounts are in accordance with Ogbu's characterization of the Chinese as having positive views on education because they are voluntary immigrants (Ogbu 1991; V. Louie 2004, 86), and also reflect their belief in education as being a necessary condition of social mobility and economic advancement (V. Louie 2004, 56). However, their racial terrain cannot be overcome by their hard-working or educational achievements. Much scholarly work shows that Asians/Asian Americans receive a smaller return on their educational achievement and have fewer chances for career advancement than white counterparts, and they encounter "glass ceiling," occupational segregation, and underrepresentation of Asian Americans at administrative positions (Suzuki 1980; Takaki 1998; San Juan 2000; Zhou and Bankston 1998; Fong 2002; Segal 2002; Tuan 2003; V. Louie 2004). According to the findings of the U.S. Glass Ceiling Commission, the salary of Asian Americans is lower than that of whites in many occupational categories: 10 to 17 percent less for Asian American men compared to whites and 40 percent less for Asian American women (Tong 2003, 147; Wu 2002, 50).

From my interviews, Chinese students said they were likely to go back to China eventually. Although they did not provide clear plans, I 
found the decisions of Chinese students are significantly different from previous stream of Chinese students and Chinese immigrants.

As pointed out by Vivian Louie, some (if not most) Chinese people do not "come to their realizations about the importance of race through social scientific research, any more than they use such research to make their conclusions about the accessibility and payoff of education" (V. Louie 2004, 56). Even though some of them have their own experiences of racial discrimination, and most of them are aware that they have entered a society with a prevailing racial hierarchy that privileges whites, Chinese students still hold up the belief that education is their way out.

\section{Discussion AND Conclusion}

With a purpose of finding out the role that race plays in Chinese graduate students' life, I explored the lived experiences of Chinese graduate students at Southwestern University. My guiding questions were: how do Chinese students experience race in everyday life? What are their interpretations of race, racial identities and racial experiences? How do racialized experiences shape their life perceptions of education and job opportunities?

To answer these questions I interviewed eleven Chinese graduate students at Southwestern, and observed two classes taught by Chinese teaching assistants and lab work of a Chinese research assistant. I found that race plays an important role in Chinese students' life through their lived experiences. Most of them have noticed race and some of them have experienced racial discrimination. However, Chinese students still hold up the importance of education and believe that education will blunt the racial edge. Despite race, language barriers and cultural differences also shape Chinese students' life. Large part of their difficulties and uncomfortable experiences are related to language barriers and cultural differences rather than racialization. It is hard to measure which indicator has the most significant effect on Chinese students' experience because they cannot be quantified. But my sense is that Chinese students may encounter language barriers more often since this relates to their everyday communication.

Racial formation theory states that most racial projects are quite benign such as color consciousness, only a few are racist. According to the experiences of my interviewees, I found the directions of racial formation are in three ways: positive, negative and neutral. In my study, in fact most of their experiences are benign. For instance, when they are aware of their race and associated racial meanings, most Chinese students do not find this bothering them. Only when some of them encounter racial discrimination, they begin to consider race a burden. To those who have 
never experienced any racial discrimination, race and racial formation remain neutral.

Before coming to the United States, Chinese students viewed race as "something far away" and "issues other countries face." After their arrival in America, Chinese students encountered a great change in racial identity and status. Used to be "Chinese," Chinese students now have to accept the new and generalized racial identity, namely, "Asian/Asian American." Their racial status also has changed-from the majority in their home country to the minority in a white dominated society. Their skin colors and phenotypes now become obstacles of their achievements, as they are racialized to be Asians, rather than whites, in the United States.

Moreover, Chinese students also face stereotypes such as the "model minority" stereotype associated with their new racial identity. Most Chinese students expressed negative views of that stereotype. Some of them considered it the academic pressure, and they thought they were "not good enough" to be the model minority. Some others pointed out that it was "racist" and the "excuse of Whites," which indicates that some Chinese students are conscious about race and racial projects. I also looked at Chinese students' academic performances, and I noticed that at graduate level, grades were no longer a significant indicator of a student's performance and achievement. Despite grade and coursework, research and teaching performance need to be addressed. This is not related to racialization, but it reflects the lived experiences of all Chinese graduate students.

Since all of the Chinese students I interviewed hold either teaching or research assistantships, I took their life as TA/RA into account. From observing two classes taught by Chinese TAs and interviewing both of those TAs, I found that Chinese TAs were lacking power. Their students did not show them enough respect. While from observing lab work of Chinese RA and interviewing him and other Chinese RAs, I noticed that there was an imbalance between their workload and salaries. More importantly, two Chinese RAs reported that they were discriminated against by their advisors. Another Chinese TA had uncomfortable experiences with his instructor. Besides, three other Chinese students talked about discrimination, prejudice or unfair treatment they received in public places including hospital, neighborhood, and super market.

Despite the racial experiences Chinese students had, they held up the belief that education would overcome their racial obstacles. They hoped that they could find jobs in the United States after graduation. Since Chinese students knew that opportunities were rare for them, they wanted to seize the chance by proving that they were "good enough" or 
"distinct," but by holding this belief, they put more pressures on themselves.

Overall, Chinese students are treated differently by different people and in different contexts. On campus, some of them are discriminated against or overworked by their professors; some of them are regarded as "model minority" by their peers. Within a context of institution of higher education, performance standards and identities of Chinese students are unique-within the school context, they could be treated unequally, but as long as they behave themselves, no one would yell at them "go back to China." However, in public spaces, when they are no longer known as graduate students, they are assigned different racial meanings - they are perceived "forever foreigners" and "outsiders." There must be differences in views and experiences between Chinese students and workers, therefore future research should include contexts other than institutions.

In addition, future research focusing on the differences in experiences among students from different Asian countries such as Japan, Korea and China is needed. There are differences among those Asian countries, but they also share a great number of similarities in phenotype and culture, therefore it will be interesting to explore the similarities and differences in their racial experiences in the United States. Moreover, international students who are not native English speakers but racialized as White (i.e. German, Italian) can be included as comparison group in this project to find out if there are any similarities or differences in their experiences. If possible, it will also be interesting to explore the experiences of Chinese students from places where Asian proportion is larger such as California and New York City. In that case, I will be able to study a larger sample size and to examine the differences in experiences of Chinese students in different contexts.

School administrations should make themselves more open to complaints such as discrimination and unfair treatment, and announcements need to be made to encourage students report their problems. I found that many Chinese students had no idea there was an Equal Opportunity Program where they could go and report discrimination. The reporters' anonymity and safety need to be guaranteed. This is especially important for international students, because they are so worried about being in trouble or losing their legal status after reporting, they choose to keep silent when they are discriminated against.

Moreover, language support programs need to be set up. The college, university and the department can set up special programs to help Asian students with their English language. For example, paper-revising workshops, mentor groups and English classes can be provided. In addition, Asian peer study groups can be conducted. Mentors from Asian 
countries can help fellow nationals with their learning and also help them adapt to the U.S. life.

\section{Works Cited}

Fong, Timonthy P. The Contemporary Asian American Experience: Beyond the Model Minority. 2nd Edition. Upper Saddle River: Prentice Hall, 2002.

Institute of International Education. 2009. "Open Doors 2009: Report on International Education Exchange," Accessed November 2009, http:// opendoors.iienetwork.org/?p=150811

Kao, Grace. "Asian American as Model Minorities? A Look at Their Academic Performance." American Journal of Education 103, 2 (1995): 121-159.

Lee, Stacey. J. Unraveling the "Model Minority" Stereotype: Listening to Asian American Youth. New York: Teachers College Press, 1996.

Louie, Andrea. Chineseness across Borders: Renegotiating Chinese Identities in China and the United States. Durham: Duke University Press, 2004.

Louie, Vivian. Compelled to Excel: Immigration, Education, and Opportunity among Chinese Americans. Stanford: Stanford University Press, 2004.

Ogbu, John. U. "Immigrant and Involuntary Minorities in Comparative Perspective." In Minority status and schooling: A comparative study of immigrant and involuntary minorities, edited by M. Gibson and J. U. Ogbu, 3-33. New York: Garland, 1991.

Omi, Michael and Howard Winant. Racial Formation in the United States: From the 1960s to the 1990s. New York: Routledge, 1994.

Pyke, Karen and Tran Dang. " 'FOB' and 'Whitewashed': Identity and Internalized Raciam Among Second Generation Asian Americans." Qualitative Sociology 26, 2, Summer (2003): 147-172.

San Juan, Epifanio, Jr. "The Limits of Ethnicity and the Horizon of Historical Materialism." In Asian-American Studies: Identity, Images, Issues, Past and Present edited by E. M. Ghymn, New York: Peter Lang Publishing, 2000.

Segal, Uma. A Framework for Immigration: Asians in the United States. New York: Columbia University Press, 2002.

Suzuki, Bob H. "Education and the Socialization of Asian Americans: A Revisionist Analysis of the "Model Minority" Thesis." In Asian-Americans: Social and Psychological Perspectives edited by R. Endo, S. 
Sue, and N. N. Wagner, 155-175. Ben Lomond: Science and Behavior Books, 1980.

Takaki, Ronald. Strangers from a Different Shore: A History of Asian Americans. Boston: Little, Brown and Company, 1998.

Tong, Benson. The Chinese Americans. Revised Edition. Boulder: the University Press of Colorado, 2003.

Tuan, Mia. Forever Foreigners or Honorary Whites: The Asian Ethnic Experience Today. New Brunswick: Rutgers University Press, 1998.

Wu, Frank H. Yellow: Race in American beyond Black and White. New York: Basic, 2002.

Zhou, Min and Carl Bankston. Growing Up American: How Vietnamese Children Adapt to Life in the United States. New York: Russell Sage Foundation, 1998. 